\title{
Population dynamics of major insect pests of cowpea [Vigna ungiculata (L.) Walp.]
}

\author{
K. SWATHI YADAV, H.V. PANDYA*, S.M. PATEL, S.D. PATEL AND M.M. SAIYAD
}

Department of Entomology, ASPEE College of Horticulture and Forestry, Navsari Agricultural University, NAVSARI (GUJARAT) INDIA

\section{ARITCLE INFO}

Received : 08.12 .2014

Revised : 13.02 .2015

Accepted : 01.03 .2015

KEY WORDS :

Cowpea, Population dynamics, Aphid, Jassid, Whitefly, Pod borer

*Corresponding author:

Email: hvpandya@nau.in

\begin{abstract}
Investigations were carried out on population dynamics of major insect pests that attack cowpea [Vigna ungiculata (L.) Walp.] at Regional Horticultural Research Station, Navsari Agricultural University, Navsari during 2012-13. The results revealed that aphid and jassid population started from $3^{\text {rd }}$ week of October, reached a peak of 3.4 aphid index and 3.8 jassids/ leaf by $1^{\text {st }}$ week of December whereas whitefly population started from $3^{\text {rd }}$ week of October and reached to a peak level of 3.7 whiteflies per leaf in $4^{\text {th }}$ week of November. Cowpea pod borer population started in $2^{\text {nd }}$ week of November and reached to a peak level ( 2.8 larvae/plant $)$ in $1^{\text {st }}$ week of December and thereafter, decreased gradually. Spotted pod borer population started from $1^{\text {st }}$ week of November coinciding with the flower initiation and reached to a peak of 2.8 larvae per leaf in $1^{\text {st }}$ week of December. Among various weather parameters, evening relative humidity showed a significantly negative influence on population of almost all pests and minimum temperature showed a significantly negative correlation with aphid, cowpea pod borer and ladybird beetle population.
\end{abstract}

How to view point the article : Yadav, K. Swathi, Pandya, H.V., Patel, S.M., Patel, S.D. and Saiyad, M.M. (2015). Population dynamics of major insect pests of cowpea [Vigna ungiculata (L.) Walp.]. Internat. J. Plant Protec., 8(1) : 112-117. 